\title{
Svabhāvapratibandha
}

\section{Shiro Matsumoto}

[Abbreviations used are the same as those in E. Steinkellner (1979): Dharmakirti's

Pramānaviniścayah, Zweites Kapitel: Svārthānumānam, II, Übersetzung und Anmerkungen, Wien, pp. 9-16]

The aim of this paper is to make clear the meaning of the term svabhavapratibandha, which is the basis of the inevitable relation between reason (hetu) and result (sädhya) in the logic of Dharmakīrti (svabhävapratibaandhe hi saty artho 'rtham na vyabhicaratil PVSV 2, 19-20).

I. E. Steinkellner translates the word svabhãvapratibandha as "eine Verknüpfung durch den Svabhāva (or durch das Wesen)", relying on the interpretation of Dharmottara1), who interpreted the compound "svabhavva-pratibandhah" as an instrumental-tatpurușa, i. e. "svabhãvena pratibandhah" (connection by svabhäva), as is clear from the following explanation:

[1] kärane svabhäve ca sädhye svabhävena pratibandhah kāryasvabhävayor avisișța (NBT 110,2-3)

Because Dharmottara equated "svabhava-pratibandhah" with "pratibaddhasvabhävatvam" (NBT 110,2), in this case the svabhava by which reason is connected with result must be construed as the svabhāva of the reason').

On the other hand, Sākyabuddhi, the oldest commentator of PVSV, interpreted the compound in question as a locative-tatpuruṣa, i. e. "svabhäve pratibandhah" (connection with svabhäva), and regarded svabhãva, the first component of the compound, as the svabhava of the result, or strictly speaking, as the real object (vastu) of the result, as is seen from the following explanations:

[2] yain cis te dinos po bsgrub pa gñis kho na yin she nal rain bshin dain ḩbrel pa (svabhāva-pratibandhe PVSV 2,19-20) shes bya ba la sogs pa smos tel rain bshin bsgrub par bya bahi dinos po (sädhyavastu) dán ḥbrel pa ni de la rag las pa ñid (äyattatva)3) de de yod nahol/ (PVT je, 12a8-b1)

[3] yata evan tasmāt svabhāvapratibandhād eva sādhyābhimate vastuni pratibaddha- 
tvād eva hetuḥ svasādhyan் gamayatil (PVSVT 76, 9-10=PVT je, 47b5-6 ; underlined: PVSV 17, 12)4)

However, the interpretations by these two commentators are inadequate, as will be made clear in this paper.

II. There are two modes of svabhavapratibandha, according to the two kinds of reason, i. e. svabhavahetu and kāryahetu ${ }^{5}$. Because the two kinds of reason do not deviate from the results only when there is svabhavapratibandha, it can be assumed that the two modes of svabhãvapratibandha will no doubt be indicated in the following definitions of the two kinds of reason:

[4] käryam svabhāvair yāvadbhir avinābhāvi kāraṇel hetuh svabhāve bhāvo 'pi bhävamātrānurodhini// (PV I k. 2)

The definition of karyahetu in this verse is commented on in PVSV as follows;

[5] kāryam svabhāvair yāvadbhir avinābhāvi kāranel teșām hetuh tatkāryatvaniyamāt tair eva dharmair ye tair vinā na bhavantil (PVSV 3, 13-16; underlined: PV I k. 2)

(tr.) The effect is, only by as many properties (particular properties) as do not arise without the properties (general properties) in the cause, the reason for the properies (general properties) in the cause, because they (the particular properties in the effect) are necessarily the effect of them (the general properties in the cause) 6 ).

Here Dharmakirti asserts that only the particular properties in the effect are the reason for only the general properties in the cause ${ }^{7)}$, because the former are necessarily the effect of the latter ${ }^{8)}$. In that case, how is the svabhavapratibandha indicated in the definition of karryahetu? The answer is given in the following passage:

[6] siddhas tu kāryakāraraṇabhāvah svabhãvam niyamayatĩty ubhayathă svabhāvapratibandhäd eva nivrttih/ (PVSV 17,6-7)

(tr.) But the relation between effect and cause, when it is established, limits svabhäva9) [of the effect]. Therefore in both cases [i. e. svabhävahetu and kārya$h e t u$, the absence [of reason in the case of the absence of result] is caused only by svabhävapratibandha. 
Here, because it is clear that the phrase "svabhavam niyamayati" explains the meaning of the word svabhavapratibandha in the case of karyahetu, "svabhäva-pratibandhah" must in this case be construed as "svabhavasya pratibandhah" (limitation of svabhäva). What then is the limitation of svabhãva which results from the establishment of the causal relation? The present writer thinks that it is the limitation of the properties in the effect to only the particular properties, which alone are the reason for the general properties in the cause, as is stated in the definition of karyahetu. Thus the svabhavapratibandha (limitation of properties) of käryahetu is expressed by the phrases "svabhāvair yāvadbhir" in PV I k. 2 and "tair eva" in Passage [5], where the limitation itself is indicated by the words "yävadbhir" and "eva".

The definition of svabhavahetu in PV I k. 2cd can be translated as follows: (tr.) Bhãva also is the reason for the svabhãva which follows only that bhãva.

The svabhavapratibandha which is indicated in this definition is explained in the following passage:

[7] tasmāt tanmātrasaṃbandhaḥ svabhāvo bhāvam eva vāl nivartayetl (PV I k. 23 abc) ......svam ca svabhāvam parityajya katham bhāvo bhavetl svabhãvasyaiva bhāvatvād iti tasya svabhāvapratibandhād avyabhicārah̆/ (PVSV 16, 28-17,3)

(tr.) Therefore the svabhava, which connects with (follows) bhãva only, when it is absent, makes only the bhäva absent. ......Bhāva cannot exist without its own svabhãva because only svabhäva is bhãva. Therefore that (bhãva, reason) does not deviate (from its svabhãva or result) because of its connection with the svabhãva.

The word "svabhava-pratibandhah" here must be construed not as "svabhävena pratibandhah" but as "svabhāve pratibandhah" (connection with svabhãva), as is commented on by Sākyabuddhi ${ }^{10)}$, because the meaning of the word "pratibandha" is here, strictly speaking, "counter-connection". The connection (sambandha) between bhäva and svabhāva has two directions. The connection of svabhāva with bhāva (svabhāva $\rightarrow b h a \bar{v} a$ connection) is anubandha11) (connection, following), while the connection of bhäva with svabhāva (bhāva $\rightarrow$ svabhāva connection) is pratibandha (counter-connection, followedness). The meaning of the term anubandha in this case is fully explained by the phrase "svabhavasyaiva 
bhävatväd", which seems to be a comment on the phrase "tanmätrasambandhah" in PV I k. 23a, as "inevitable following of svabhava to bhava", i. e. "inevitable occurrence of svabhava in the case of the occurrence of bhava". In the definition of svabhavahetu, by stating that the connection of svabhava with bhãva is anubandha (lit. anurodha), the connection of bhava with svabhä$v a$ is defined as pratibandha.

Svabhäva is the "essence" (ātman) of bhäva, as is clear from Passage [7]. Therefore, in the logical context, the relation of bhavva to svabhava is tādat. mya ${ }^{12)}$ (having that [=result] as its essence), while the relation of svabhãva to $b h \bar{a} v a$ is tadbhāvatata ${ }^{13)}$ (having that [=reason] as its bhāva or essence-possessor). Thus the term tādatmya must not be translated, as is done by Steinkellner'14), by "identity", if otherwise the limiting word "eva" in the phrase "svabhāvasyaiva bhãvatvä" can mean nothing.

The conclusion of this paper is shown in the following table ${ }^{15}$.

kāryasya svabhāvasya pratibandhah (limitation of its properties)

bhāvasya svabhāve pratibandhah (counter-connection with its essence)

1) Cf. E. Steinkellner (1971): Wirklichkeit und Begriff bei Dharmakīrti, WZKS 15, p. 202, n. 87; do. (1979), p. 44, n. 111.

2) Cf. Steinkellner's statement "Nur diese beiden Gründe sind nämlich durch ihren Svabhāva mit der entsprechenden Folge verbunden." (E. Steinkellner (1971), p. 205).

3) Cf. PVT je, 31b4-5 (=tatpratibandhāel tatra kāraṇe àyattatvādl PVSVT 55,89). For Dharmottara also, the connection of reason with result is "ayattatva" (dependence), while, for Dharmakirti, the term is employed to express the connection of the result with the reason called svabhãva, i. e. svabhävahetu. Cf. NBT 112, 1-2; PVSV 4, 3.

4) Karnakagomin is later than Sākyabuddhi and Dharmottara, because their passages (PVT je, 15a3-4; Dh dse, 308b6-309a1) are quoted by him (PVSV 28, 20; $28,21-24)$.

5) Cf. sa ca tadātmatvät/ (PVSV 2, 20-21); kāryasyāpi svabhāvapratibandhahl tatsvabhāvasya tadutpatter itil (PVSV 3,3-4).

6) This translation is based mainly on the explanation in HBT $(151,7-13 ; 151,20$ 152, 1).

7) This assertion is already made by Dignāga in PS II kk. 18-19 (ce, 5a3-4).

8) Cf. tad evam käranasya sāmannyadharmā eva gamyā na viśeșadharmāh, kāryasyāpi visesșadharmā eva gamakā na sāmānyadharmāh, tatkāryatvaniyamātl (HBT 
$152,1-4)$.

9) This translation does not seem to contradict Sākyabuddhi's comment "kāryasya svabhāvam kārane niyamayati" (PVSVT 75,22=PVT je, 47b1-2), because the property of the effect is fixed on the cause by limiting the properties of the effect.

10) Cf. tasyātmabhütasya sādhanasya simśapādeh svabhāvapratibandhād eva svabhāve sādhyābhimate vrkșādau yathoktena prakärena pratibandhād evāvyabhicārahl (PVS VT 75, 14-15=PVT je, 47a6-7; underlined: PVSV 17, 2-3).

11) Cf. yathāsamnihitān nānyam apekșata iti tanmatrānubandhī svabhāvo bhāvasyal (PVSV 6, 26-27). It is declared in PS II k. 13 (4b7-8) that whatever follows a particular thing is obtained through anyapoha. Therefore svabhava which follows bhava, being the result of anyäpoha, cannot be real.

12) Cf. tadātmyam hy arthasya tanmätrānurodhiny eva nānyāyattel (PVSV 4,2-3). The present writer does not accept Steinkellner's interpretation that the word "tadätman" from which the abstract noun "tädatmya" is derived is a tatpurusacompound, but rather Dharmottara's interpretation that the word is a bahuvrinicompound meaning "what has that as its atman or svabhäva". Cf. sa sädhyo 'rtha àtmā svabhãvo yasya tat tadātmäl tasya bhãvas tādātmyam/ (NBT 113,3-4); E. Steinkellner (1974): On the interpretation of the svabhävahetuh, $W Z K S$ 18, p. 118 , n. 2. Steinkellner's opinion might rest on the following passages: tasmin sādhye yo hetuh sa svabhāvaḥ tasya sādhyasya nānyah̆/l (NBT 106,6-7), sādhyadharmasya śrutatvāt tasyaiva svabhāva iti gamyatel (HBT 57,6-7). However, because such expressions were merely contrived by the commentators owing to the fact that svabhavahetu is called svabhäva by Dharmakirti himself, it is not proper to use them in determining the meaning of such important term as tädatmya. As for the compound "lingi-svabhava" in "lingisvabhava eva-hetuh" (HB 39, 12; read according to Tib.), in spite of the interpretation by Arcața, which is accepted by Steinkellner, that it is a tatpurusa-compound (HBT 57,6-7, 11-12), the present writer considers it to be a bahuvrihi-compound, because the meanings of the words "svabhava" in the compound and in the sentence "pare hy arthantaranimittam atadbhävamātrānvayinam api dharmam svabhävam icchanti” (HB 39, 14-15) must be the same. Cf. E. Steinkellner (1974), p. 126.

13) Cf. sādhyadharmasya vastutas tadbhãvatayä (HB 37,3-4).

14) Cf. E. Steinkellner (1974), p. 118.

15) It is not clear whether the present writer's interpretation agrees in its content with that of the commentators who, prior to Dharmottara, construed the compound "svabhävapratibandhah" as a genitive-tatpurușa in the case of kāryahetu, and as a locative-tatpuruṣa in the case of svabhāvahetu. Cf. DhPr 110, 17-19;E. Steinkellner (1979), p. 44, n. 111.

* My thanks is due to Mr. Keiichi Miyamoto, Mr. Atsushi Kanazawa, Mr. Hiroshi Marui and Mr. Yoichi Fukuda, whose suggestions were very useful in writing this paper. 